\title{
HUBUNGAN POLIMORFISME GEN RESEPTOR ESTROGEN ALFA DENGAN JUMLAH SEL T CD4+ PADA ANAK TERINFEKSI HIV
}

\author{
Irna Sufiawati ${ }^{*}$ Risti Saptarini**, Eriska Riyanti**
}

\section{Keywords:}

Children, HIV, ERa

polymorphism, Pvull, Xbal

\section{ABSTRACT}

Background: Estrogen plays a key role in human physiological processes. Polymorphisms of estrogen receptors have been implicated in the development of numerous diseases. The aim of this study was to evaluate the frequency of ERa gene Pvull and Xbal polymorphisms and assessing their association with CD4+ T-cell counts in HIV-infected children on highly active antiretroviral therapy.

Methods: CD4+ T cell counts were determined using the FACS count system. ERa Pvull and Xbal polymorphisms were analyzed by PCR-RFLP.

Results: This study enrolled 34 HIV-infected children on HAART. The frequencies of the Pvull and Xbal gene polymorphisms were PP 41,2\%, Pp $26,5 \%$, pp $32,4 \%$ and XX 35,3\%, Xx 17,6\%, xx 47,1\% respectively. CD4+ T-cell counts were significantly associated with Xbal polymorphisms $(p<0.05)$, but not Pvull polymorphisms $(p>0.01)$.

Discussion: Host genetic factor polymorphism is an important determinant of HIV disease progression and treatment response. The ERa Pvull and Xbal polymorphisms can increase risk for the development of HIV-related complication, including oral diseases.

Conclusion: The ERa gene Xbal polymorphism was significantly associated with CD4+ T-cell counts. It may explain the role of estrogen in the regulation of HIV replication. Studying human genetic variation in HIV-infected individuals is important to guide a new therapeutic approach.

\section{INTRODUCION}

Estrogen is one form of the class of steroid hormone that consists of estradiol (E2), estrone and estriol. Estrogen plays a key role in many human physiological processes that range from the development and maintenance of reproductive organs to the regulation of cardiovascular, musculoskeletal, immune, and central nervous system homeostasis. ${ }^{1-3}$ Physiological and metabolic effects of estrogens are mediated by the nuclear estrogen receptors (ERs), named estrogen alpha (ER $\alpha)$ and estrogen receptor beta $(E R \beta)$, which distinct tissue and cell patterns of expression. ${ }^{3,4}$
The common ERs polymorphisms associated with the expression of the estrogen receptors are Pvull (IVS1-397 T/C; rs2234693) and Xbal (IVS1-351 A/C; rs9340799) that are the most widely studied so far. $^{5}$

It has been shown that ERs receptors have been detected in oral mucosa and salivary glands. The presence of ER mRNA and immunoreactive ER protein suggests that estrogens have a biological role in oral mucosa and salivary glands. ${ }^{6,7}$ Throughout the last year, an increasing number of studies have studied the relationships between genetic polymorphisms of Pvull and Xbal and numerous diseases. As the oral mucosa contains estrogen receptors, 
variations in estrogen levels can affect oral mucosa directly or through neural mechanism affect the oral cavity. ${ }^{8}$ The previous findings showed that estrogen may be involved in the development or progression of numerous oral diseases, including oral leukoplakia, oral squamous cell carcinoma (OSCC), periodontal disease, xerostomia, burning mouth syndrome (BMS), and temporomandibular joint disorders (TMJD). ${ }^{9-11}$

The amount of attention has been given to the relationship between estrogen and HIV. It has been demonstrated a contribution of estrogen for HIV-1 replication through ERa by augmenting Sp1 DNA-binding and transcriptional activity. ${ }^{12}$ In addition, antiretroviral drugs, such as nonnucleoside reverse transcriptase inhibitors, have been showed to be associated with increased levels of estrogen. ${ }^{13}$ It is rare to find recent data on estrogen and its receptor in HIV-infected population, especially in HIVinfected children. While children with advanced immunosuppression may frequently develop estrogen-related diseases, including in oral cavity. At present, genotype distribution of ERa gene Pvull and Xbal polymorphisms and their association with HIV-diseases progression has not been reported. It is known well that HIV infection and AIDS among children continues to be a significant problem in developing countries including in Indonesia. This study was conducted to find out an association between ERa gene Pvull and Xbal polymorphisms with $\mathrm{CD} 4^{+} \mathrm{T}$-cell counts as a marker of the degree of immunosuppression in HIV-infected children on highly active antiretroviral therapy (HAART).

\section{METHODS}

\section{Ethics Statement}

The study protocol was reviewed and approved by Ethical Committee of Faculty of Medicine, Universitas Padjadjaran number 275/UN6.C1.3.2/KEPK/PN/2015. All the parents of children provided written informed consent.

\section{Study participants}

The present study enrolled 34 (thirty-four) HIV-infected children under HAART, aged between 6 and 14 years. All study participants were diagnosed HIV positive at Dr. Hasan Sadikin General Hospital.

\section{CD4+ T cell count, genomic DNA extraction and polymorphisms analysis}

Blood samples were collected from the study participants and the CD4+ T-cell counts were determined using the Becton Dickinson (BD) FACS Count system. The genomic DNA was extracted from whole blood using the established protocol for DNA extraction from blood cells. The Pvull and Xbal polymorphisms of ERa were analyzed by polymerase chain reaction restriction fragment length Polymorphism (PCR-RFLP) as described previously. ${ }^{15}$

\section{Statistical analysis}

Data entry and analysis were done using software SPSS version 13. Quantitative data were presented by mean and standard deviation. Qualitative data were presented by frequency distribution. One-way ANOVA and Kruskal-Wallis test were used to detect the mean difference across the two genotypes and the $\mathrm{CD}^{+}{ }^{+} \mathrm{T}$-cell counts. A confidence interval (Cl) level was set to $95 \%$ where any output $p$ $<0.05$ would be interpreted as an indicator of statistical significant. 


\section{RESULTS}

\section{Characteristics of the study participants}

The distributions of characteristics of the thirty-four (34) HIV-infected children on HAART recruited in this study are summarized in Table 1. The gender distributions of the study participants were $16(47,1 \%)$ males and $18(52,9 \%)$ females. Their mean age was 9 years $(S D \pm 3)$, ranging from 6 to 14 years. The mean duration of HAART use was 5 years. The mean CD4+ T-cell counts of the study participants was $724(18-1805)$ cell/mm3 and 8 participants reported to have CD4 count < 200 cells. Distribution of CD4+ T-cell counts of the study participants was shown in Tabel 2 . The mean of CD4+ T-cell counts of the study participants was cell $/ \mathrm{mm}^{3}$, and 8 participants reported to have severe immunosuppression $(<200 / \mathrm{mm} 3)<200 \mathrm{cell} / \mathrm{mm}^{3}$.

\section{Genotype frequency and its association with the CD4+ T-cell counts}

The genotype distributions of the ERa gene Pvull and Xbal polymorphism among HIV-infected children on HAART are shown in Table 3. Genotype Pvull polymorphism was distributed as follows: PP 41,2\% ( $n=14), P p$ $26,5 \%(n=9), p p 32,4 \%(n=11)$. The frequency of Xbal polymorphism was $X X 35,3 \%(n=12)$,

Tabel 1. Characteristics of the study participants

\begin{tabular}{lcc}
\hline \multicolumn{1}{c}{ Characteristics } & Number of subjecs & $\%$ \\
\hline Gender, N (\%) & 16 & 47,1 \\
- Male & 18 & 52,9 \\
- Female & $9 \pm 3$ & \\
Age (years), Mean \pm SD & $5 \pm 2$ & \\
Duration of HAART exposure (years), Mean \pm SD & $724(18-1805)$ \\
CD4 Absolut & $23,72 \pm 10,77$ \\
CD4 \% & \\
\hline
\end{tabular}

Table 2. CD4 T-cell counts in relation to the degree of immunosuppression of the study participants.

\begin{tabular}{lcc}
\hline \multicolumn{1}{c}{ Category } & $\begin{array}{c}\text { Number of } \\
\text { subjecs }\end{array}$ & $\begin{array}{c}\text { CD4 T-cell counts } \\
\text { Mean/ SD }\end{array}$ \\
\hline No significant immunosuppresion $\left(>500 / \mathrm{mm}^{3}\right)$ & 24 & $946,08 \pm 386,94$ \\
Mild immunosuppresion $\left(350-499 \mathrm{cell} / \mathrm{mm}^{3}\right)$ & 1 & 452 \\
Advanced immunosuppresion $\left(200-349 \mathrm{cell} / \mathrm{mm}^{3}\right)$ & 1 & 313 \\
Severe immunosuppresion $\left(<200 \mathrm{cell} / \mathrm{mm}^{3}\right)$ & 8 & $104,63 \pm 45,78$ \\
\hline
\end{tabular}


Table 3. Frequency distribution of the ESRa gene Pvull and Xbal polymorphisms in HIV infected children on HAART.

\begin{tabular}{ccc}
\hline Genotype & Number of subjects & $\%$ \\
\hline Estrogen Receptor Pvull & 14 & 41,2 \\
- PP & 9 & 26,5 \\
- Pp & 11 & 32,4 \\
\hline - pp & 12 & \\
\hline Estrogen Receptor Xbal & 6 & 35,3 \\
- XX & 16 & 17,6 \\
$-\quad$ Xx & & 47,1 \\
\hline
\end{tabular}

Table 4. Analysis of the association between ESRa gene Pvull and Xbal polymorphisms and CD4+T-cell counts in HIV-infected children on HAART

\begin{tabular}{|c|c|c|c|}
\hline The $\operatorname{ESR} \alpha$ gene polymorphisms & $\mathbf{N}(\%)$ & $\begin{array}{l}\text { CD T-cell counts } \\
\text { Median (range) }\end{array}$ & p-value \\
\hline \multicolumn{4}{|l|}{ Estrogen Receptor Pvull } \\
\hline - PP & $14(41,2)$ & $570(18-1777)$ & \\
\hline$-\mathrm{Pp}$ & $9(26,5)$ & $932(107-1805)$ & 0,175 \\
\hline - Pp & $11(32,4)$ & $691(126-1537)$ & \\
\hline \multicolumn{4}{|l|}{ Estrogen Receptor Xbal } \\
\hline$-\mathrm{XX}$ & $12(35,3)$ & $560(18-1234)$ & \\
\hline$-X x$ & $6(17,6)$ & $1203(107-1805)$ & $0,031^{*}$ \\
\hline$-x x$ & $16(47,1)$ & $724(126-1777)$ & \\
\hline
\end{tabular}

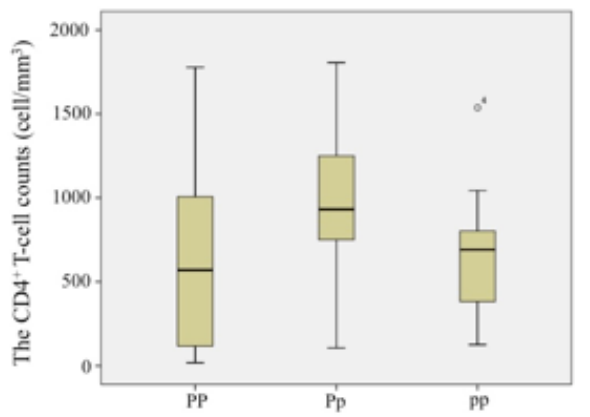

A. The ESR $\alpha$ Pvull polymorphisms

B.

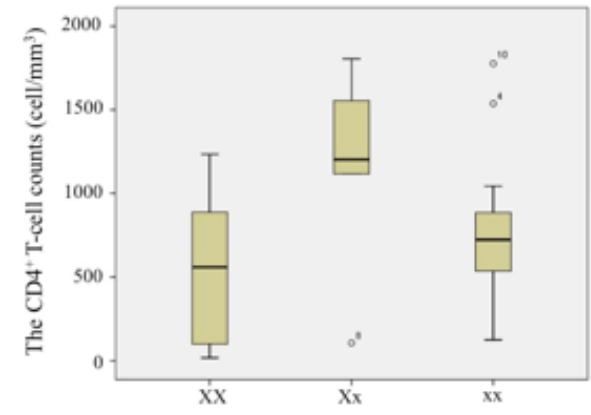

The ESR $\alpha$ Xbal polymorphisms

Figure 1. Distribution of the association of the ESRa Pvull polymorphisms (A) and Xbal polymorphisms (B) with CD4+ T-cell counts in HIV-infected children on HAART. 
$X x 17,6 \%(n=6), x x 47,1 \%(n=16)$. Analysis for the association of ERa gene Pvull and Xbal polymorphism with $\mathrm{CD}^{+}{ }^{+}$T-cell counts were shown in Table 4. It was observed significant association of the Xbal polymorphism with CD4 ${ }^{+}$T-cell counts $(p<0.05)$. In subjects with $X x$ and $x x$ genotype have a higher median of CD4 ${ }^{+}$T-cell counts than in subjects with $X X$ genotype. Whereas, there was no significant association were seen for Pvull polymorphism with $\mathrm{CD} 4^{+} \mathrm{T}$-cell counts.

\section{DISCUSSION}

Host genetic factors have been shown to have an important role as a determinant of HIV disease progression. ${ }^{15}$ HIV-disease progression in young children is more rapidly than in adults, the effects of host genetic factors on HIV disease progression may be more clearly identified. It has been suggested that host genetic polymorphisms influence the risk of developing numerous diseases in HIV-infected people. ${ }^{16-18}$ Estrogene hormone is well known to play an essential role in the growth and development during childhood and estrogen receptors (ERs) mediate much estrogen action.

In this study, we have analyzed the frequency distribution of the ESRa Pvull and Xbal polymorphisms in HIV-infected children on HAART and their association with CD4 ${ }^{+}$T-cell counts. Clinical monitoring of infected persons relies on monitoring of $\mathrm{CD} 4^{+} \mathrm{T}$-cell counts and viral load used as a predictor of disease progression and the risk for development of HIV-related complication. Our data showed that PP genotype of ERa gene Pvull polymorphism more frequent than $\mathrm{Pp}$ and $\mathrm{pp}$ genotype. Whereas, the frequencies of $x x$ and Xx genotype of ERa gene Xbal polymorphism were higher than $\mathrm{XX}$ genotype. Furthermore, Xbal polymorphisms significantly associated with $\mathrm{CD} 4^{+} \mathrm{T}$-cell counts in HIV-infected children on HAART. While, there was no significant association were seen for Pvull polymorphism with $\mathrm{CD} 4^{+} \mathrm{T}$-cell counts. In subjects with $\mathrm{Xx}$ and $\mathrm{xx}$ genotype have a higher median of $C D 4^{+} \mathrm{T}$ cell counts than in subjects with $X X$ genotype. It has been reported the direct inhibitory effect of $17 \beta$-estradiol, the most bioactive form of estrogen, inhibits HIV replication. ${ }^{19}$ Prior studies has been reported that the common ERa polymorphisms and Xbal and Pvull as possible markers for several human diseases and these genotype variations have been implicated in the occurrence of numerous diseases. ${ }^{20-22}$

The host genetic factors may alter the response to antiretroviral. HAART is wellestablished have an important role to reduce the frequency of opportunistic infections and the number of AIDS-related deaths. However, the adverse effects of HAART use have been reported with the use of all antiretroviral (ARV) drugs. ${ }^{23}$ Prior studies demonstrated the influence of antiretroviral therapy on growth hormone therapy in HIV-infected patients. Nonnucleoside reverse transcriptase inhibitors were associated with 17beta-estradiol, the most bioactive form of estrogen. ${ }^{24}$ It has also been reported that genetic polymorphisms of estrogen receptors in HIV-infected patients on HAART. ${ }^{25}$ Another study suggested that the efavirenz directly induced growth tissue through direct binding and modulation of estrogen receptor. ${ }^{26}$

Estrogen receptors have been detected in oral mucosa and salivary glands, hence it is suggested that estrogens have a biological role in oral mucosa and salivary glands. Prior studies have been reported that some 
genetic changes had any effect on oral cavity.

These findings could be applicable in oral health therapy. Besides, other factors such as microorganisms, chronic irritation and sex hormones along with underlying genetic factors may also contribute to pathogenesis of oral diseases. ${ }^{9-11}$ Genetic polymorphisms of estrogen receptors related to oral disease have not been investigated by any study so far. Recognition of the susceptibility genes for HIV-related oral diseases may also important to initial prevention of disease.

The present study had some limitations. The size of the population studied was relatively small. Therefore, a larger population is required to establish the potential role of the genetic polymorphisms of estrogen receptors as a modifier gene in disease progression in HIV population. During the past decade, the majority of studies investigating the influence of human genetic variation related to HIV disease and treatment response. Much research has established that host genetic factors are important determinants HIV disease progression in children as well as adults. Several anti-HIV-1 gene therapy approaches have been studied, including T-cells gene therapy as co-option for anti-HIV treatment. ${ }^{27}$ The impact of human genetic variation on HIV pathogenesis and treatment response is a complex multi factorial phenomenon, which still remains to be fully elucidated and understood.

\section{CONCLUSIONS}

We summarized that the ERa gene Xbal polymorphism significantly associated with CD4+T-cell counts in HIV-infected children on HAART. The relationship between genes determining disease progression and drug response requires much further study focus on the role of ERa that may help to identify therapeutic or diagnostic markers. HIVinfected children are at increased risk for growth and development disorders and estrogen-associated diseases, which might be influenced by a number of genotypic factors. These findings emphasize the important of studying human genetic variation to guide a new therapeutic approach. A comprehensive study of the molecular genetic variation can be used to predict pharmacological response.

\section{ACKNOWLEDGMENT}

We are grateful to members of Teratai Clinic and the Clinical Pathology Laboratory of the referral Hasan Sadikin Hospital, Bandung, West Java, Indonesia for generous assistance, data collection and their laboratory help. This project was supported by the Directorate General of Higher Education, Ministry of National Education

\section{CONFLICT OF INTEREST}

The authors declare no conflict of interests.

\section{REFERENCES}

1. Deroo BJ, Korach KS. Estrogen receptors and human disease. J Clin Invest. 2006; 116:561-70.

2. Cadenas C, Bolt HM. Estrogen receptors in human disease. Arch Toxicol. 2012; 86:1489-90.

3. Heldring N, Pike A, Andersson S, Matthews J, Cheng G, Hartman J, et al. Estrogen receptors: how do they signal and what are their targets. Physiol Rev 2007; 87:905-931. 6.

4. Casazza K, Page GP, Fernandez JR. The association between the rs2234693 and rs9340799 estrogen receptor gene polymorphisms and risk factors for cardiovascular disease. Biol. Res. Nurs. 2010; 12(1): 84-97.

5. Westberg L, Eriksson E. Sex steroid related candidate genes in psychiatric disorders. J. Psychiatry Neurosci. 2008; 33:319-330.

6. Leimola-Virtanen R, Salo T, Toikkanen S, Pulkkinen J, Syrjänen S. Expression of estrogen receptor (ER) in oral mucosa and salivary glands. Maturitas. 2000; 
$36: 131$

7. Välimaa H, Savolainen $S$, Soukka $T$, Silvoniemi $P$, Mäkelä S, Kujari $\mathrm{H}$, et al. Estrogen receptor-beta is the predominant estrogen receptor subtype in human oral epithelium and salivary glands. J Endocrinol. 2004; 180:55-62.

8. Cao M, Shu L, Li J, Su J, Zhang W, Wang Q, et al. The expression of estrogen receptors and the effects of estrogen on human periodontal ligament cells. Methods Find Exp Clin Pharmacol. 2007; 29:329-35.

9. Meurman JH, Tarkkila L, Tiitinen A. The menopause and oral health. Maturitas. 2009; 63:56-62.

10. Ribeiro-Dasilva MC, Peres Line SR, Leme Godoy dos Santos MC, Arthuri MT, Hou W, Fillingim RB, Rizzatti Barbosa CM: Estrogen receptor-alpha polymorphism and predisposition to TNJ disorder. J Pain. 2009, 10: 527-533.

11. Sridharan G, Ramani P. Patankar S, Vijayaraghavan $\mathrm{R}$. Analysis of estrogen metabolites in oral leukoplakia and oral squamous cell carcinoma. Int J Pharm Bio Sci 2017 Jan; 8(1): (B) 552-556.

12. Susana N. Asin, Alysha M. Heimberg, Susan K. Eszterhas, Christiane Rollenhagen, and Alexandra L. Howell. AIDS Research and Human Retroviruses. 2008 May; 24(5): 701-716.

13. Collazos J, Martinez E, Mayo J, Ibarra S. Sexual hormones in HIV-infected patients: the influence of antiretroviral therapy. AIDS. 2002; 16(6): 934-937.

14. Bittencourt-Oliveira MC, Cunha M.C.C., Moura A.N.M. Genetic polymorphism in Brazilian microcystis spp. (cyanobacteria) toxic and Non-toxic through RFLPPCR of the cpcBA-IGS. Braz. Arch. Biol. Technol. 2009; 54(4): 901-909.

15. Singh KK, Spector SA: Host genetic determinants of HIV infection and disease progression in children. Pediatr Res. 2009, 65: 55R-63R.

16. Diaz-Arrastia R, Gong Y, Kelly CJ, Gelman BB. Host genetic polymorphisms in human immunodeficiency virus-related neurologic disease. J Neurovirol. 2004; 10 (Suppl 1):67-73.

17. de Almeida ER, Reiche EM, Kallaur AP, Flauzino T, Watanabe MA. The roles of genetic polymorphisms and human immunodeficiency virus infection in lipid metabolism. Biomed Res Int 2013; 2013: 836790

18. Kallianpur AR, Levine AJ. Host genetic factors predisposing to HIV-associated neurocognitive disorder. Curr HIVIAIDS Rep. 2014; 11:336-52.

19. Szotek EL, Narasipura SD, Al-Harthi L. $17 \beta$-estradiol inhibits HIV-1 by inducing a complex formation between $\beta$-catenin and estrogen receptor $\alpha$ on the HIV promoter to suppress HIV transcription. Virology. 2013; 443:375-383.

20. Sobczuk A, Smolarz B, Romanowicz-Makowska H. Estrogen receptor alpha (ER-alpha) gene polymorphism in patients from the Lodz region of Poland with sporadic endometrial cancer. Eur J Gynaecol Oncol 2009; 30:431-434.

21. Wedrén S, Lovmar L, Humphreys K. Estrogen receptor alpha gene polymorphism and endometrial cancer risk-a case-control study. BMC Cancer 2008; 8: 322.

22. Chang HM, Cheng YJ, Su CK, et al. Association of estrogen receptor a gene Pvull and Xbal polymorphisms with non-small cell lung cancer. Oncol. Lett. 2012; 3:462-468.

23. Khan K, Khan AH, Sulaiman SA, Soo CT, Ahsan R. Adverse Effect of Highly Active Anti-Retroviral Therapy (HAART) in HIVIAIDS Patients. Indian Journal of Pharmacy Practice. 2014; 7:29.

24. Collazos J, Martínez E, Mayo J, Ibarra S. Sexual hormones in HIV-infected patients: the influence of antiretroviral therapy. AIDS. 2002; 16:934-7.

25. Gasparotto AS, Sprinz E, Lazzaretti RK, et al. Genetic polymorphisms in estrogen receptors and sexual dimorphism in fat redistribution in HIV-infected patients on HAART. AIDS. 2012; 26(1):19-26.

26. Sikora MJ, Rae JM, Johnson MD, Desta Z: Efavirenz directly modulates the oestrogen receptor and induces breast cancer cell growth. HIV Med. 2010, 11: 603-607.

27. Rossi JJ, June $\mathrm{CH}$, Kohn DB. Genetic therapies against HIV. Nat. Biotechnol. 2007; 25:1444-1454. 